\title{
Prophylactic effects of probiotics on respiratory viruses including COVID-19: a review
}

\author{
Na-Kyoung Lee ${ }^{1} \cdot$ Hyun-Dong Paik ${ }^{1}$ (1)
}

Received: 25 March 2021/Revised: 15 April 2021/Accepted: 21 April 2021/Published online: 24 May 2021

(C) The Author(s) 2021

\begin{abstract}
Coronavirus disease 2019 (COVID-19), caused by the severe acute respiratory syndrome coronavirus 2 (SARS-CoV-2), is mainly transmitted through respiratory droplets. The symptoms include dry cough, fever, and fatigue; however, high propagation, mutation, and fatality rates have been reported for SARS-CoV-2. This review investigates the structure of SARS-CoV-2, antiviral mechanisms, preventive strategies, and remedies against it. Effective vaccines have been developed by Pfizer (95\% effective), AstraZeneca (90\% effective), Moderna (94.5\% effective) vaccine, among others. However, herd immunity is also required. Probiotics play a major role in the gut health, and some are known to have therapeutic potential against viral infections. Their modes of antiviral activities include direct interaction with targeted viruses, production of antiviral metabolites, and immunomodulatory effects on the host. Hence, probiotics can be a useful prophylactic against COVID-19, and more studies are required on the effects of probiotics against other viral infections that may occur in future.
\end{abstract}

Keywords COVID-19 - Probiotics · Prophylactic effect · Gut microbiome $\cdot$ Immunomodulatory effect

Hyun-Dong Paik

hdpaik@konkuk.ac.kr

1 Department of Food Science and Biotechnology of Animal Resources, Konkuk University, Seoul 05029, Republic of Korea

\section{Introduction}

Coronaviruses are enveloped positive-sense RNA virus with spike (Richman et al., 2016). General coronaviruses can cause mild respiratory diseases. Severe diseases have occurred in humans over the past two decades by the crossover of animal betacorona viruses. First, severe acute respiratory syndrome coronavirus (SARS-CoV) was reported in 2002-2003 in the Guangdong province of China. Then, the Middle East respiratory syndrome coronavirus (MERS-CoV) of bat origin was reported in Saudi Arabia with dromedary camels acting as the intermediate host, infecting 2,492 people and caused 858 deaths (fatality rate 34\%) (WHO, 2021). Coronavirus disease 2019 (COVID-19) is caused by the severe syndrome coronavirus 2 (SARS-CoV-2), and originated in China's Hubei province. COVID-19 was reported in 2019, and recognized as a pandemic on March 11, 2020 by the WHO, eventually spreading in 213 countries, and resulting in more than 120 millions infections and over 2.65 millions deaths worldwide as of March 15, 2021 by WHO.

Probiotics are known to confer health benefits on the host when administered in appropriately amounts (FAO/ WHO, 2006), and are used as functional foods for human welfare. Probiotics paly a role in balancing the intestinal microflora and modulating the immune system. Recently, research on probiotics has improved our understanding of the modulation of the gut-liver axis, gut-lung axis, and gutbrain-axis, through the production of $\operatorname{IgA}$ and brain-derived neurotrophic factor (BDNF) by the gut microbiome (Vajro et al., 2013). However, probiotics have limitations such as viability control and side effects on hosts; therefore, postbiotics and parabiotics have been investigated as well (Nataraj et al., 2020). Postbiotics are metabolic products of probiotics, such as enzymes, proteins, short chain fatty 
acids, vitamins, and amino acids, while parabiotics are probiotics inactivated by physical or chemical treatments, which are therefore stable with regard to production and storage, and are considered safer due to lack of side effects such as sepsis.

COVID-19 targets people of all ages, and spreads through large droplets generated during coughing and sneezing by symptomatic patients. SARS-CoV-2 is characterized by high mutation rates. Some patients with COVID-19 show intestinal microbial dysbiosis, and the application of probiotics can balance the intestinal microbiota and reduce the risk of secondary infection (Xu et al., 2020). Therefore, this review deals with the general characteristics of COVID-19 and potential probiotic-related therapeutic strategies for antiviral effects.

\section{Structure of SARS-CoV-2 and symptoms of COVID- 19}

SARS-CoV-2 virus is an enveloped, positive sense, singlestrand RNA viruses (genome size: $26-32 \mathrm{~kb}$ ) belonging to the large family of Coronaviridae and subfamily Orthocoronavirinae, members of which infect birds and mammals (Coronaviridae study group of The International Committee on Taxonomy of Viruses, 2020). SARS-CoV-2 binds to angiotensin-converting enzyme 2 (ACE2) receptors on host cells via its spike glycoprotein, which consists of two domains (S1 and S2). S1 binds to the peptidase domain of ACE2, while S2 catalyzes membrane fusion, thereby leading to entry of the viral genetic material into host cell (Hoffmann et al., 2020a, 2020b). The viral RNA codes for structural proteins such as replicase, envelope protein, spike protein, membrane protein, and nucleoprotein; and several non-structural proteins, such as uncharacterized protein 14 , and protein $9 \mathrm{~b}$ (Ou et al., 2020). Nonstructural proteins participate in host-protein interactions and modulate host-cell signaling pathways.

The primary infection results from viral transmission through close contact with respiratory droplets from the infected person. The general symptoms of COVID-19 have been reported to be high temperature, dry cough, fever, fatigue, myalgia, and dyspnea (WHO, 2021). Other symptoms include headache, sore throat, rhinorrhea, and gastrointestinal symptoms. The symptoms of COVID-19 manifest after 2-14 days of contact, with latent periods of up to 14 days. The clinical features of COVID-19 vary, and are indistinguishable from other respiratory infections. Adverse outcomes and death are more common among the elderly. Infections in infants and children have been reported to be significantly milder than in adults.

\section{Antiviral agents and their mechanisms}

The RNA genetic material of COVID-19 has $\sim 29,811$ nucleotides, which encode approximately 29 proteins, which include: structural proteins (4 proteins), nonstructural proteins (16 proteins), and accessory proteins (9 proteins) (Khailany et al., 2020). The four structural proteins are the envelope and membrane proteins that form the viral envelope, nucleocapsid protein that binds to the viral RNA, and the spike $S$ protein that binds to the human ACE2 receptor present on the host cell surface.

Antiviral mechanisms target the life cycle of the virus. The viral life cycle can generally be divided into early- and advanced stages. The therapeutic strategy against COVID19 has so far involved blocking the early stage of the viral life cycle (Al-Horani et al., 2020), and clathrin-mediated endocytosis (Yang and Shen, 2020).

Quinoline derivatives have been investigated in various settings for the treatment of coronavirus infection (AlHorani et al., 2020). At the beginning of the COVID-19 pandemic, chloroquine and hydroxychloroquine were authorized for emergency use by the U.S. FDA (U.S. FDA, 2020). Chloroquine was shown to block SARS-CoV-2 infection at a low micromolar concentration in VeroE6 cells (Wang et al., 2020). Chloroquine appears to inhibit the glycosylation of the host ACE2 receptor, which interferes with binding of the virus to the host receptor (U.S. FDA, 2020; Vincent et al., 2005). In addition, chloroquine and hydroxychloroquine have been shown to increase the endosomal/ lysosomal $\mathrm{pH}$, and thus disrupt the viral entry into the host cell (Vincent et al., 2005). However, chloroquine or hydroxychloroquine did not show antiviral effects in patients with COVID-19 (U.S. FDA, 2020).

Antiviral drugs, such as ribavirin and lopinavir-ritonavir, have been used for SARS and MERS. Serious adverse effects have been reported with the use of quinoline-based antimalarial dugs, and chloroquine has been linked to cardiac arrhythmias and retinopathy. Arbidol (an antiviral drug available in Russia and China), plant extracts, intravenous immunoglobulin, interferons, chloroquine, and convalescent plasma, have been investigated for their antiviral effects (Ahn et al., 2020; Bae et al., 2019; Jin et al., 2020; Zhang et al., 2020). Polyphenols have also been used for the prevention of COVID-19 in view of their immune-boosting properties (Mehany et al., 2021). For antiviral therapy, tocilizumab has been used against COVID-19 with/without corticosteroids in February 2021 (NIH, 2019). It is recommended that tocilizumab be administered in combination with dexamethasone. In addition, hospitalized patients were treated for hypoxemia with remdesivir, dexamethasone plus remdesivir, or dexamethasone; and immunotherapy involved administration of corticosteroids, interleukin (IL)-1 or IL-6 inhibitors. 
Vaccines are in demand for herd immune, and herd immune might be achieved before 2022. Some vaccines have been permitted for use (BBC News, 2021). Pfizer/ BioNtech vaccine has up to $95 \%$ effective; however, the vaccine must be stored at a temperature of approximately $-70{ }^{\circ} \mathrm{C}$. The Oxford University/AstraZeneca vaccine has 70-90\% efficacy. And the data also showed a strong immune response in the elderly. This may be one of the easiest vaccines to distribute because it does not need to be stored at very cold temperatures. The Moderna vaccine has $94.5 \%$ efficacy. It is easier to store than the Pfizer's vaccine because it remains stable at $-20{ }^{\circ} \mathrm{C}$ for up to six months. The Russian Sputnik V vaccine has $92 \%$ efficacy. The Wuhan Institute of Biological Products and Sinopharm in China, and Russia's Gamaleya Research Institute, are all in the final testing stages of their respective vaccines. Sinovac (China) has shown 50.4\% efficacy in Brazil. Although vaccines are prophylactics against COVID-19, their efficacy is limited by multiple mutations in the virus, such as those giving rise to the UK and South Africa strains, and by their side effects (headache, fever, muscle ache, etc.). In addition, these vaccines are reported to cause severe allergic reactions after vaccine injection in some people.

\section{Prophylactic therapy by probiotics}

The human gut microbiome consists of approximately 1000 different species of microbes, with densities of $10^{4}-$ $10^{5} \mathrm{CFU} / \mathrm{mL}$ of the digestive tract in the small intestine and $10^{11} \mathrm{CFU} / \mathrm{g}$ of luminal content of the colon (Kastl et al., 2020). The gut microbiome principally comprises of four groups, namely Firmicutes, Bacteriodetes, Proteobacteria, and Actinobacteria (Sweeney and Morton, 2013). The gut microbiome can help fight infection by competing against pathogens, colonization ability, and metabolite production (e.g., organic acids, antimicrobial compounds, and short chain fatty acids) (Jang et al., 2019).

The gut microbiome influences the health of the host, its imbalance being involved in many conditions such as lung disorders, including asthma, chronic obstructive pulmonary disease, chronic bronchitis, emphysema, lung cancer, pneumonia, pleural effusion, viral infection, and infection (Han et al., 2007). It is also recognized that viral infections in the respiratory tract cause disturbances in the gut microbiome, which points to the existence of the gut-lung axis (Dhar and Mohanty, 2020). Changes in the gut microbiome due to respiratory viral infections have been demonstrated using microbiome analysis and metabolome analysis (Groves et al., 2020). Table 1 showed the relatedness of the viral infection and the gut microbiome. Viral infection results in an increase in the Bacteriodetes/Firmicutes ratio, and a decrease in microbial diversity in the gut microbiome (Grayson et al., 2018). These changes in gut microbiome result in anorexia by increasing the levels of sphingolipids, polyunsaturated fatty acids (PUFAs), and short-chin fatty acid (SCFA) valerate (Scencio et al., 2020; $\mathrm{Yu}$ et al., 2019a). In addition, communication between microbiota and environmental factors affects mucosal immunity (Neish and Jones, 2014). The mucus layer present on the surface of the gastrointestinal tract, respiratory tract, and vaginal tract is the first line of defense, where immunoglobulin A antibody acts as the first line of mucosal immunity (Corthesy, 2013).

Probiotics have been defined as live microbes that confer health benefits on the host when administered in appropriately amounts (FAO/WHO, 2006; Lee et al., 2019). Probiotics can balance the intestinal microflora, which are involved in the epithelial barrier of intestines, competition with disease-causing agents, attachment to the epithelial wall of intestines, production of anti-pathogen elements, and enhancement of the immune system of the host (Abdulamir and Hafidh, 2020; Jang et al., 2019; Kariyasawasam et al., 2020). Bifidobacterium bifidum and Streptococcus thermophilus showed a decline in diarrheal incidents and reduction of rotavirus titers in a meta-analysis (Szajewska et al., 2019). The maintenance of commensal bacteria can influence immune homeostasis during invasion by influenza A virus and coronavirus through the gastrointestinal tract. Some probiotics and parabiotics have been reported to reduce the titers of influenza virus, although the underlying mechanism remains to be understood (Park et al., 2018).

Probiotics and their metabolites help maintain commensal microbiota despite viral infection (H1N1 and PR8 virus) (Ichinohe et al., 2011). Figure 1 shows the antiviral potentials of probiotics and their metabolites through direct or indirectly interfere with the viral life cycle (Al Kassaa et al., 2014). They exert antiviral activity by direct probiotic-virus interaction, production of antiviral inhibitory metabolites, and indirect modulation of the immune system. Lactic acid bacteria (LAB) and their bacteriocins can serve as antiviral agents (Al Kassaa et al., 2014). LAB are known to synthesize exopolysaccharides, which may confer health benefits to humans, including through immunomodulatory, antitumor, antibiofilm, and antioxidant activities (Jang et al., 2020). In addition, some probiotics, such as Lactobacillus fermentum CECT5716, have been found to enhance the effects of influenza vaccination by inducing an antibody response (Olivares et al., 2007).

\section{Direct probiotic-virus interaction}

Some probiotics or their metabolites have been reported to directly inhibit human immunodeficiency virus (HIV) (D'Angelo et al., 2017) and transmissible gastroenteritis virus (TGEV) (Chai et al., 2013). However, the direct 
Table 1 Findings of recent investigations of the activity of gut microbiome against influenza virus

\begin{tabular}{|c|c|c|}
\hline Virus & Findings & References \\
\hline Influenza virus & $\begin{array}{l}\text { Increase in IFN-I levels in lung/production of desaminotyrosine by gut microbe Clostridium } \\
\text { orbiscindens }\end{array}$ & $\begin{array}{l}\text { Steed et al. } \\
(2017)\end{array}$ \\
\hline $\begin{array}{l}\text { Influenza virus } \\
\quad(\mathrm{H} 1 \mathrm{~N} 1)\end{array}$ & Gut microbiome increased anti-inflammatory cytokine (IL-10 and IL-14) levels in H1N1 infection & $\begin{array}{l}\text { Rosshart et al. } \\
\text { (2017) }\end{array}$ \\
\hline Sendai virus & $\begin{array}{l}\text { The use of streptomycin in viral infection led to reduction of intestinal microbial diversity } \\
\text { These variations influence the increase in mortality and immune responses at distant mucosal sites } \\
\text { (decrease in Treg population/increase in IFN- } \gamma \text {, IL-6, and CCL1 levels) }\end{array}$ & $\begin{array}{l}\text { Grayson et al. } \\
\text { (2018) }\end{array}$ \\
\hline $\begin{array}{l}\text { Influenza virus } \\
(\mathrm{H} 1 \mathrm{~N} 1 / \mathrm{H} 3 \mathrm{~N} 2)\end{array}$ & Decrease in short chain fatty acid concentration as dysbiosis & $\begin{array}{l}\text { Scencio et al. } \\
\text { (2020) }\end{array}$ \\
\hline
\end{tabular}

$C C L$ CC chemokine ligand, $I F N$ interferon, $I L$ interleukin

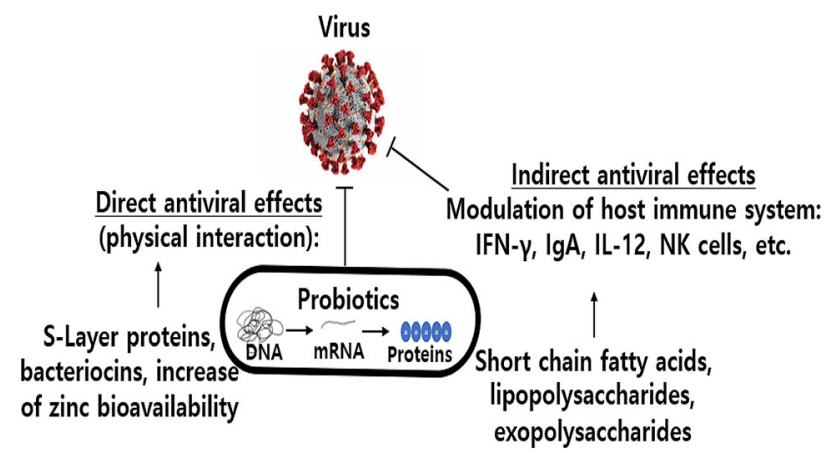

Fig. 1 Mechanisms of action of antiviral probiotics against respiratory viruses. Abbreviation: $I F N$ interferon, $I g$ immunoglobulin, $I L$ interleukin, $N K$ natural killer

inhibition of the influenza virus was limited. Enterococcus faecium NCIMB 10415 inhibits influenza virus (H1N1 and H3N2) via direct physical interaction (Wang et al., 2013). The S-layer protein of Lactobacillus acidophilus ATCC 4356 inhibits the invasion by and replication of the H9N2 virus (Gao et al., 2016).

In the vesicular stomatitis virus (VSV)-cell culture model, Bifidobacterium longum Q46, Lactobacillus paracasei A14, and Lactobacillus plantarum M1.1 have demonstrated antiviral activity (Botic et al., 2007). Their possible mechanisms include: (1) hindering the adsorption of the VSV, (2) inhibition of virus protection, and (3) production of metabolites with a direct antiviral effect.

Probiotic metabolites include organic acids, bacteriocins, hydrogen peroxide, and its metabolites, which play a role in the health of gut microbiome and host immunity (Tiwari et al., 2020). These substances can inactivate human immunodeficiency virus type I (HIV-1) and herpes simplex virus type 2 (HSV-2) (Conti et al., 2009; Tuyama et al., 2006).

Bacteriocins are ribosomally synthesized antimicrobial peptides with bactericidal activity (Lee et al., 2013). Table 2 shows the antiviral effects of bacteriocins.
Enterocin ST4V and CRL35 inhibit HSV-1 or HSV-2 and target the multiplication of viral particles (Todorov et al., 2005; Wachsman et al., 1999a, 1999b). A bacteriocin originating from Lactobacillus delbrueckii subsp. bulgaricus 1043 inhibits influenza virus (H7N1 and H7N7) (Serkedjieva et al., 2000). Until now, the mechanism underlying the antiviral effects of bacteriocins have not been uncovered; therefore, more research is necessary in this field.

\section{Increase of zinc bioavailability}

Zinc plays an important role in membrane integrity, DNA synthesis, and cell proliferation (Read et al., 2019). In addition, zinc is associated with the improvement of the host's reaction to various infections and plays a significant role in maintaining host homeostasis (Read et al., 2019). Zinc supplementation resulted in a vital reduction in sickness in children with pneumonia (Rerksuppaphol and Rerksuppaphol, 2019).

Lactobacillus fermentum SR4 and Lactobacillus rhamnosus GG have been reported to increase zinc bioavailability in intestinal cells (Lule et al., 2020). These two strains can chelate zinc at high ratios of $57.9 \%$ and $48.2 \%$, respectively, when compared with the commercial chelate (Zn-sulfate (16.1\%) and Zn-gluconate (26.9\%)).

\section{Modulation of immune system}

Probiotics can influence immunity through various cytokines produced by dendritic cells (DCs), monocytes or macrophages, and B and T lymphocytes (Kawashima et al., 2011). Probiotics are effective against several ailments, including viral infections (Kanauchi et al., 2018). The numbers and the activity of natural killer (NK) cells are also significantly improved by IL-2 activation (Grudzien and Rapak, 2018; Takeda et al., 2006). Innate immunity can benefit from acquired immunity, which is mediated by 
Table 2 Antiviral effects and mode of action of some bacteriocins

\begin{tabular}{|c|c|c|c|}
\hline Bacteriocin (producer) & Virus & Mode of action & References \\
\hline Bacteriocin (Lactobacillus delbrueckii) & Influenza virus (H7N7, H7N1) & $\begin{array}{l}\text { Inhibition of invasion and } \\
\text { replication } \\
\text { of virus }\end{array}$ & Serkedjieva et al. (2000) \\
\hline $\begin{array}{l}\text { Peptide ST4V (Enterococcus mundtii } \\
\text { ST4V) }\end{array}$ & $\begin{array}{l}\text { Herpes simplex viruses-1, polio } \\
\text { virus (PV3, strain Sabin), and } \\
\text { a measles virus (MV/BRAZIL/ } \\
\text { 001/91) }\end{array}$ & $\begin{array}{l}\text { Aggregation of the viral particles } \\
\text { or blocking of their receptor } \\
\text { sites }\end{array}$ & Todorov et al. (2005) \\
\hline $\begin{array}{l}\text { Enterocin CRL35 } \\
\text { (Enterococcus mundtii CRL35) }\end{array}$ & Herpesvirus & Inhibition of viral replication & $\begin{array}{l}\text { Wachsman et al. } \\
\text { (1999a, 1999b) }\end{array}$ \\
\hline $\begin{array}{l}\text { Enterocin ST5Ha } \\
\text { (Enterococcus faecium ST5Ha) }\end{array}$ & Herpesvirus-1 & $\begin{array}{l}\text { Aggregation of viral particles, } \\
\text { blockage } \\
\text { of receptor sites on the host cell }\end{array}$ & Todorov et al. (2010) \\
\hline $\begin{array}{l}\text { Enterocin CRL35 } \\
\text { (Enterococcus mundtii CRL35) }\end{array}$ & Herpesvirus (HSV-1, HSV-2) & Inhibition of viral replication & Wachsman et al. (2003) \\
\hline $\begin{array}{l}\text { Subtilosine KATMIRA } 1933 \\
\text { (Bacillus amyloliquefaciens } \\
\text { KATMIRA 1933) }\end{array}$ & Herpesvirus-1 & $\begin{array}{l}\text { In high concentrations, inhibition } \\
\text { of viral particle formation and } \\
\text { release }\end{array}$ & Torres et al. (2013) \\
\hline
\end{tabular}

Toll-like receptors (TLRs) (Belkaid and Hand, 2014). Probiotics can also induce the production of antigen-presenting cell (APC)-derived cytokines (IL-10, IL-12, IL-17, tumor necrosis factor (TNF)- $\alpha$, etc.) through activation of adaptive immunity. Proinflammatory cytokines, chemokines, and their receptors are inhibited by the anti-inflammatory cytokine IL-10, produced by various immuneactivated cells (Azad et al., 2018). As a result, probiotics can have two different types of immunomodulatory effects on inflammation: the immunostimulatory effect, which activates IL-12 production, and induces NK, Th1, and Th2 cells; and immunoregulatory effect, which induces IL-10 and $\mathrm{T}_{\text {reg }}$ cell activation by Th2, DCs, B cells, and monocytes, through overexpression of cytokines (Chiba et al., 2010).

In some cases, COVID-19 can cause extreme storms of inflammatory cytokines, including IL-2, IL-17, IL-10, granulocyte colony-stimulating factor (GCSF), interferon gamma-inducible protein (IP)-10, monocyte chemoattractant protein (MCP)-1, macrophage inflammatory protein (MIP) 1- $\alpha$, and TNF- $\alpha$ (Chen et al., 2020). Table 3 lists the various antiviral probiotics and their probable mechanisms. L. plantarum CRL1506 has demonstrated antiviral properties through modulation of the intestinal immune response (Mizuno et al., 2020). The major antiviral active factor of L. plantarum CRL1506 may be lipoteichoic acid (LTA). L. plantarum YU has been shown to exert antiviral effects against H1N1 virus by inducing IL-2 secretion
(Kawashima et al., 2011). Heat-killed L. plantarum L-138 exerts antiviral immunomodulatory effects by inducing interferon (IFN)- $\beta$ (Maeda et al., 2009). L. plantarum 200655 and Lactobacillus paraplantarum SC61 have demonstrated immune-enhancing effects (Son et al., 2018; Yang et al., 2019). As stated above, the active factor behind these immunomodulatory effects of heat-killed probiotics might be LTA, a surface glycolipid found in gram-positive bacteria. Some probiotics, such as L. plantarum KU15149 and Weissella cibaria JW15 exert anti-inflammatory effects by LPS stimulation (Han et al., 2020; Yu et al., 2019b).

In conclusion, this review investigates the use of probiotics as prophylactics or treatment aids for therapy against COVID-19. Outbreaks caused by zoonotic coronaviruses can result in severe human casualties. Viral infection can lead to gut dysbiosis according to several reviewers. Some probiotics can regulate host homeostasis through immunomodulatory effects and the maintenance of the gut microbiome. However, the use of probiotics is limited as a therapeutic agent. Probiotics have also been shown to reduce the side effects of chemotherapy. The species and mechanisms behind antiviral probiotics vary. Therefore, probiotics can be used as prophylactic medicinal foods against viral infection. Further study is therefore required, to understand the beneficial effects of probiotics against viral infections and their potential use in antiviral therapy. 
Table 3 Antiviral effects and mode of action of some probiotics against respiratory viruses

\begin{tabular}{|c|c|c|c|}
\hline Probiotics & Virus & Mode of action & References \\
\hline Enterococcus faecium NCIMB 10415 & $\begin{array}{l}\text { Swine influenza virus } \\
(\mathrm{H} 1 \mathrm{~N} 1, \mathrm{H} 3 \mathrm{~N} 2)\end{array}$ & $\begin{array}{l}\text { Direct physical interaction/ } \\
\text { Strengthening of innate defenses }\end{array}$ & Wang et al. (2013) \\
\hline Lactobacillus acidophilus ATCC 4356 S-layer protein & $\mathrm{H} 9 \mathrm{~N} 2$ & $\begin{array}{l}\text { Inhibition of invasion by and } \\
\text { replication of virus; stimulation } \\
\text { of type I IFN signaling pathway }\end{array}$ & Gao et al. (2016) \\
\hline Lactobacillus casei Shirota & Influenza viruses, RV & $\begin{array}{l}\text { Activation of immature immune } \\
\text { system: activation of NK cells } \\
\text { and IL-12 production }\end{array}$ & Yasui et al. (2004) \\
\hline Lactobacillus plantarum $\mathrm{YU}$ & $\begin{array}{l}\text { Influenza virus } \\
(\mathrm{H} 1 \mathrm{~N} 1)\end{array}$ & $\begin{array}{l}\text { Activation of Th1 immune } \\
\text { response/IgA production }\end{array}$ & $\begin{array}{l}\text { Kawashima et al. } \\
\text { (2011) }\end{array}$ \\
\hline Heat-killed Lactobacillus plantarum L-137 & $\begin{array}{l}\text { Influenza virus } \\
\text { (H1N1) }\end{array}$ & $\begin{array}{l}\text { Immunomodulation; IFN- } \beta \\
\text { induction }\end{array}$ & Maeda et al. (2009) \\
\hline $\begin{array}{l}\text { Lactobacillus fermentum CECT5716/Lactobacillus casei } \\
\text { DN114-001 }\end{array}$ & Influenza virus & Increase in the antibody response & $\begin{array}{l}\text { Boge et al. (2009) and } \\
\text { Olivares et al. (2007) }\end{array}$ \\
\hline Lactobacillus rhamnosus CRL1505 & $\begin{array}{l}\text { Respiratory syncytial } \\
\text { virus }\end{array}$ & Production of IFN-c and ILs & Villena et al. (2011) \\
\hline $\begin{array}{l}\text { Lactobacillus rhamnosus GG/Bifidobacterium animalis } \\
\text { subsp. lactis } \text { BB-12/ Lactobacillus acidophilus NCFM/ } \\
\text { Bifidobacterium animalis subsp. lactis } \text { BI-07/heat } \\
\text { killed Lactobacillus pentosus b240 }\end{array}$ & $\begin{array}{l}\text { Respiratory virus } \\
\text { infections }\end{array}$ & Immunomodulation & $\begin{array}{l}\text { Kiso et al. (2013), } \\
\text { Leyer et al. (2009), } \\
\text { and Rautava et al. } \\
\text { (2009) }\end{array}$ \\
\hline Lactobacillus plantarum NCIMB 8826 & $\begin{array}{l}\text { Respiratory syncytial } \\
\text { virus, pneumovirus }\end{array}$ & $\begin{array}{l}\text { TLR-dependent inflammatory } \\
\text { response }\end{array}$ & Al Kassaa et al. (2014) \\
\hline Lactobacillus casei DN-114001 & $\begin{array}{l}\text { Respiratory tract } \\
\text { infection, } \\
\text { rhinopharyngitis, } \\
\text { influenza }\end{array}$ & $\begin{array}{l}\text { Enhancement of defensin } \\
\text { expression and innate immunity }\end{array}$ & $\begin{array}{l}\text { Guillemard et al. } \\
\text { (2010) }\end{array}$ \\
\hline Lactobacillus rhamnosus M21 & Pneumonia, influenza & Increase in IFN- $\gamma$ and IL-2 levels & Song et al. (2016) \\
\hline Lactococcus lactis JCM 5805 & $\begin{array}{l}\text { Respiratory tract } \\
\text { infection }\end{array}$ & $\begin{array}{l}\text { Activation of plasmacytoid } \\
\text { dendritic cells }\end{array}$ & Kokubo et al. (2019) \\
\hline $\begin{array}{l}\text { Lactobacillus fermentum CECT5716/Lactobacillus } \\
\text { plantarum DK119 }\end{array}$ & Influenza virus & $\begin{array}{l}\text { Activation of innate immunity: } \\
\text { increase in IL-12, IFN- } \gamma \text {; } \\
\text { decrease in IL-4, IL- } 6 \text {, and TNF- } \\
\alpha \text { levels }\end{array}$ & $\begin{array}{l}\text { Olivares et al. (2007) } \\
\text { and Park et al. (2013) }\end{array}$ \\
\hline
\end{tabular}

IFN interferon, $I g$ immunoglobulin, $I L$ interleukin, $N K$ natural killer, $T N F$ tumor necrosis factor, $T L R$ toll-like receptor

\section{Declaration}

Conflict of interest The authors have no financial conflicts of interest to declare.

Open Access This article is licensed under a Creative Commons Attribution 4.0 International License, which permits use, sharing, adaptation, distribution and reproduction in any medium or format, as long as you give appropriate credit to the original author(s) and the source, provide a link to the Creative Commons licence, and indicate if changes were made. The images or other third party material in this article are included in the article's Creative Commons licence, unless indicated otherwise in a credit line to the material. If material is not included in the article's Creative Commons licence and your intended use is not permitted by statutory regulation or exceeds the permitted use, you will need to obtain permission directly from the copyright holder. To view a copy of this licence, visit http://creativecommons. org/licenses/by/4.0/.

\section{References}

Abdulamir AS, Hafidh RR. The possible immunological pathways for the variable immunopathogenesis of COVID-19 infections among healthy adults, elderly and children. Electron Journal of General Medicine 17: 202 (2020)

Ahn DG, Shin HJ, Kim MH, Lee S, Kim HS, Myoung J, Kim BT, Kim SJ. Current status of epidemiology, diagnosis, therapeutics, and vaccines for novel coronavirus disease 2019 (COVID-19). Journal of Microbiology and Biotechnology 30: 313-324 (2020)

Al Kassaa I, Hober D, Hamze M, Chihib NE., Drider D. Antiviral potential of lactic acid bacteria and their bacteriocins. Probiotics and Antimicrobial Proteins 6: 177-185 (2014)

Al-Horani RA, Kar S, Aliter KF. Potential anti-COVID-19 therapeutics that block the early stage of the viral life cycle: Structures, mechanisms, and clinical trials. International Journal of Molecular Science 21: 5224 (2020)

Azad AK, Sarker M, Wan D. Immunomodulatory effects of probiotics on cytokine profiles. BioMed Research International 2018: 8063647 (2018) 
Bae WY, Kim HY, Choi KS, Chang KH, Hong YH, Eun J, Lee NK, Paik HD. Investigation of Brassica juncea, Forsythia suspensa, and Inula britannica: phytochemical properties, antiviral effects, and safety. BMC Complementary and Alternative Medicine 19: 253 (2019)

BBC News. Covid vaccine update: When will others be ready? https://www.bbc.com/news/health-51665497. Accessed Feb. 2, 2021.

Belkaid Y, Hand T. Role of the microbiota in immunity and inflammation. Cell 157: 121-141 (2014)

Boge T, Remigy M, Vaudaine S, Tanguy J, Bourdet-Sicard R, van der Werf S. A probiotic fermented dairy drink improves antibody response to influenza vaccination in the elderly in two randomised controlled trials. Vaccine 27: 5677-5684 (2009)

Botic T, Klingberg TD, Weingartl H, Cencic A. A novel eukaryotic cell culture model to study antiviral activity of potential probiotic bacteria. International Journal of Food Microbiology 115: 227-234 (2007)

Chai W, Burwinkel M, Wang Z, Palissa C, Esch B, Twardziok S, Rieger J, Wrede P, Schmidt MFG. Antiviral effects of a probiotic Enterococcus faecium strain against transmissible gastroenteritis coronavirus. Archives of Virology 158: $799-807$ (2013)

Chen N, Zhou M, Dong X, Qu J, Gong F, Han Y, Qiu Y, Wang J, Liu $\mathrm{Y}$, Wei $\mathrm{Y}$, et al. Epidemiological and clinical characteristics of 99 cases of 2019 novel coronavirus pneumonia in Wuhan, China: A descriptive study. Lancet 395: 507-513 (2020)

Chiba Y, Shida K, Nagata S, Wada M, Bian L, Wang C, Shimizu NT, Yamashiro Y, Kiyoshima-shibata J, Nanno M, et al. Wellcontrolled proinflammatory cytokine responses of Peyer's patch cells to probiotic Lactobacillus casei. Immunology 130: 352-362 (2010)

Conti C, Malacrino C, Mastromarino P. Inhibition of herpes simplex virus type 2 by vaginal lactobacilli. Journal of Physiology and Pharmacology 60: 19-26 (2009)

Coronaviridae study group of the international committee on taxonomy of viruses. The species severe acute respiratory syndromerelated coronavirus: classifying $2019-\mathrm{nCoV}$ and naming it SARS-CoV-2. Nature Microbiology 5: 536-544 (2020)

Corthesy B. Multi-faceted functions of secretory $\operatorname{IgA}$ at mucosal surfaces. Frontiers in Immunology 4: 185 (2013)

D'Angelo C, Reale M, Costantini E. Microbiota and probiotics in health and HIV infection. Nutrients 9: 615 (2017)

Dhar D, Mohanty A. Gut microbiota and COVID-19- possible link and implications. Virus Research 285: 198018 (2020)

FAO/WHO. Report on joint FAO/WHO expert consultation on evaluation of health and nutritional properties of probiotics in food including powder milk with live lactic acid bacteria. Cordoba, Argentina (2006)

Gao X, Huang L, Zhu L, Mou C, Hou Q, Yu Q. Inhibition of H9N2 virus invasion into dendritic cells by the S-layer protein from $L$. acidophilus ATCC 4356. Frontier in Cellular and Infection Microbiology 6: 137 (2016)

Grayson MH, Camarda LE, Hussain SRA, Zemple SJ, Hayward M, Lam V, Hunter DA, Santoro JL, Rohlfing M, Cheung DS, et al. Intestinal microbiota disruption reduces regulatory $\mathrm{T}$ cells and increases respiratory viral infection mortality through increased IFN- $\gamma$ production. Frontiers in Immunology 10: 1587 (2018)

Groves HT, Higham SL, Moffatt MF, Cox MJ, Trgoning JS. Respiratory viral infection alters the gut microbiota by inducing inappetence. mBio 11: e03236 (2020)

Grudzien M, Rapak A. Effect of natural compounds on NK cell activation. Journal of Immunology Research 2018: 4868417 (2018)

Guillemard E, Tondu F, Lacoin F, Schrezenmeir J. Consumption of a fermented dairy product containing the probiotic Lactobacillus casei DN-114 001 reduces the duration of respiratory infections in the elderly in a randomised controlled trial. British Journal of Nutrition 103: 58-68 (2010)

Han MK, McLaughlin VV, Criner GJ, Martinez FJ. Pulmonary diseases and the heart. Circulation 116: 2992-3005 (2007)

Han KJ, Lee JE, Lee NK, Paik HD. Antioxidant and anti-inflammatory effect of probiotic Lactobacillus plantarum KU15149 derived from Korean homemade diced-radish kimchi. Journal of Microbiology and Biotechnology 30: 591-598 (2020)

Hoffmann M, Kleine-Weber H, Pöhlmann SA. Multibasic cleavage site in the spike protein of SARS-CoV-2 is essential for infection of human lung cells. Molecular Cell 78: 779-784 (2020a)

Hoffmann M, Kleine-Weber H, Schroeder S, Kruger N, Herrler T, Erichsen S, Schiergens TS, Herrler G, Wu NH, Nitsche A, et al. SARS-CoV-2 cell entry depends on ACE2 and TMPRSS2 and is blocked by a clinically proven protease inhibitor. Cell 181: 271-280 (2020b)

Ichinohe T, Pang I, Kumamoto Y, Peaper DR, Ho JH, Murray TS, Iwasaki A. Microbiota regulates immune defense against respiratory tract influenza A virus infection. Processings of the National Academy of Sciences of the Unites States of America 108: 5354-5359 (2011)

Jang HJ, Lee NK, Paik HD. Probiotic characterization of Lactobacillus brevis KU15153 showing antimicrobial and antioxidant effect isolated from kimchi. Food Science and Biotechnology 28: 1521-1528 (2019)

Jang HJ, Yu HS, Lee NK, Paik HD. Immune-stimulating effect of Lactobacillus plantarum Ln1 isolated from the traditional Korean fermented food, kimchi. Journal of Microbiology and Biotechnology 30: 926-929 (2020)

Jin YH, Cai L, Cheng ZS, Cheng H, Deng T, Fan YP, Fang C, Huang D, Huang LQ, Huang Q, et al. A rapid advice guideline for the diagnosis and treatment of 2019 novel coronavirus [2019-nCoV] infected pneumonia [standard version]. Military Medical Research 7: 4 (2020)

Kanauchi O, Andoh A, AbuBakar S, Yamamoto N. Probiotics and parabiotics in viral infection: Clinical application and effects on the innate and acquired immune systems. Current Pharmaceutical Design 24: 710-717 (2018)

Kariyasawasam KMGMM, Yang SJ, Lee NK, Paik HD. Probiotic properties of Lactobacillus brevis KU200019 and synergistic activity with fructooligosaccharides in antagonistic activity against foodborne pathogens. Food Science of Animal Resources 40: 297-310 (2020)

Kastl AJ Jr., Terry NA, Wu GD, Albenberg LG. The structure and function of the human small intestinal microbiota: Current understanding and future directions. Cellular and Molecular Gastroenterology and Hepatology 9: 33-45 (2020)

Kawashima T, Hayahi K, Kosaka A, Kawashima M, Igarashi T, Tsutui H, Tsuji NM, Nishimura I, Hayashi T, Obata A. Lactobacillus plantarum strain YU from fermented foods activates Th1 and protective immune responses. International Immunopharmacology 11: 2017-2024 (2011)

Khailany RA, Safdar M, Ozaslan M. Genomic characterization of a novel SARS-CoV-2. Gene Reports 19: 100682 (2020)

Kiso M, Takano R, Sakabe S, Katsura K, Shinya K, Uraki R. Protective efficacy of orally administered, heat-killed Lactobacillus pentosus b240 against influenza A virus. Scientific Reports 3: 1563 (2013)

Kokubo T, Komano Y, Tsuji R, Fujiwara D, Fujii T, Kanauchi O. The effects of plasmacytoid dendritic cell-stimulative lactic acid bacteria, Lactococcus lactis strain plasma, on exercise-induced fatigue and recovery via immunomodulatory action. International Journal of Sport Nutrition and Exercise Metabolism 29: 354-358 (2019)

Lee NK, Han EJ, Han KJ, Paik HD. Antimicrobial effect of bacteriocin KU24 produced by Lactococcus lactis KU24 against 
methicillin-resistant Staphylococcus aureus. Journal of Food Science 78: M465-M469 (2013)

Lee NK, Kim WS, Paik HD. Bacillus strains as human probiotics: characterization, safety, microbiome, and probiotic carrier. Food Science and Biotechnology 28: 1297-1305 (2019)

Leyer GJ, Li S, Mubasher ME, Reifer C, Ouwehand AC. Probiotic effects on cold and influenza-like symptom incidence and duration in children. Pediatrics 124: e172-e179 (2009)

Lule VK, TOmar SK, Chawla P, Pophaly S, Kalila S, Arora S. Bioavailability assessment of zinc enriched lactobacillus biomass in a human colon carcinoma cell line (Caco-2). Food Chem. 309: 125583 (2020)

Maeda N, Nakamura R, Hirose Y, Murosaki S, Yamamoto Y, Kase T, Yoshikai Y. Oral administration of heat-killed Lactobacillus plantarum L-137 enhances protection against influenza virus infection by stimulation of type I interferon production in mice. International Immunopharmacology 9: 1122-1125 (2009)

Mehany T, Khalifa I, Barakat H, Althwab SA, Alharbi YM, ElSohaimy S. Polyphenols as promising biologically active substances for preventing SARS-CoV-2: A review with research evidence and underlying mechanisms. Food Biosci. 40: 100891 (2021)

Mizuno H, Arce L, Tomotsune K, Albarracin L, Funabashi R, Vera D, Islam MA, Vizoso-Pinto MG, Takashi H, Sasaki Y, et al. Lipoteichoic acid is involved in the ability of the immunobiotic strain Lactobacillus plantarum CRL 1506 to modulate the intestinal antiviral innate immunity triggered y TLR3 activation. Frontiers in Immunology 11: 571 (2020)

Nataraj BH, Ali SA, Behare PV, Yadav H. Postbiotics-parabiotics: the new horizons in microbial biotherapy and functional foods. Microbial Cell Factories 19: 168 (2020)

Neish AS, Jones RM. Redox signaling mediates symbiosis between the gut microbiota and the intestine. Gut Microbes 5: 250-253 (2014)

NIH. Coronavirus disease 2019 (COVID-19) treatment guidelines. Available at: https://www.covid19treatmentguidelines.nih.gov/. Accessed March, 15, 2021.

Olivares M, Diaz-Ropero MP, Sierra S, Lara-Villoslada F, Fonolla J, Navas M, Rodriguez JM, Xaus J. Oral intake of Lactobacillus fermentum CECT5716 enhances the effects of influenza vaccination. Nutrition 23: 254-260 (2007)

Ou X, Liu Y, Lei X, Li P, Mi D, Ren L, Gou R, Guo R, Chen T, Hu J, et al. Characterization of spike glycoprotein of SARS-CoV-2 on virus entry and its immune cross-reactivity with SARS-CoV. Nature Communications 11: 1620 (2020)

Park MK, Ngo V, Kwon YM, Lee YT, Yoo S, Cho YH, Hong SM, Hwang HS, Ko EJ, Jung YJ, et al. Lactobacillus plantarum DK119 as a probiotic confers protection against influenza virus by modulating innate immunity. PLoS One 8: e75368 (2013)

Park S, Kim JI, Bae JY, Yoo K, Kim H, Kim IH, Park MS, Lee I. Effects of heat-killed Lactobacillus plantarum against influenza viruses in mice. Journal of Microbiology 56: 145-149 (2018)

Rautava S, Salminen S, Isolauri E. Specific probiotics in reducing the risk of acute infections in infancy a randomised, double-blind, placebo-controlled study. British Journal of Nutrition 101: 1722-1726 (2009)

Read SC, Obeid S, Ahlenstiel C, Ahlenstiel G. The role of zinc in antiviral immunity. Advances in Nutrition 10: 696-710 (2019)

Rerksuppaphol S, Rerksuppaphol L. A randomized controlled trial of zinc supplementation in the treatment of acute respiratory tract infection in Thai children. Pediatric Reports 11: 7954 (2019)

Richman DD, Whitley RJ, Hayden FG. Clinical Virology, 4th ed. ASM Press, Washington, DC, USA (2016)

Rosshart SP, Vassallo BG, Angeletti D, Hutchinson DS, Morgan AP, Takeda K, Hickman HD, McCulloch JA, Hadger JH, Ajami NJ, et al. Wild mouse gut microbiota promotes host fitness and improves disease resistance. Cell 171: 1015-1028 (2017)

Scencio V, Bartherlemy A, Tavares LP, Machado MG, Soulard D, Cuinat C, Queiroz-Junior CM, Noordine M, Salome-Desnoulez $\mathrm{S}$, Deryuter L, et al. Gut dysbiosis during influenza contributes to pulmonary pneumococcal superinfection through altered shortchain fatty acid production. Cell Reports 20: 2934-2947 (2020)

Serkedjieva J, Danova S, Ivanova I. Antiinfluenza virus activity of a bacteriocin produced by Lactobacillus delbrueckii. Applied Biochemistry and Biotechnology 88: 285-298 (2000)

Son SH, Yang SJ, Jeon HL, Yu HS, Lee NK, Park YS, Paik HD. Antioxidant and immunostimulatory effect of potential probiotic Lactobacillus paraplantarum SC61 isolated from Korean traditional fermented food, jangajji. Microbial Pathogenesis 125: 486-492 (2018)

Song JA, Kim HJ, Hong SK, Lee DH, Lee SW, Song CS, Kim KT, Choi KS, Lee JB, Park SY. Oral intake of Lactobacillus rhamnosus M21 enhances the survival rate of mice lethally infected with influenza virus. Journal of Microbiology, Immunology and Infection 49: 16-23 (2016)

Steed AL, Chrisophi GP, Kaiko GE, Sun L, Goodwin VM, Jain U, Esaulova E, Artyomov MN, Morales DJ, Holtzman MJ, et al. The microbial metabolite desaminotyrosine protects from influenza through type I interferon. Science 357: 498-502 (2017)

Sweeney TE, Morton JM. The human gut microbiome. JAMA Surgery 148: 563-569 (2013)

Szajewska H, Kołodziej M, Gieruszczak-Białek D, Skórka A, Ruszczyński M, Shamir R. Systematic review with metaanalysis: Lactobacillus rhamnosus GG for treating acute gastroenteritis in children - a 2019 update. Alimentary Pharmacology and Therapeutics 49: 1376-1384 (2019)

Takeda K, Suzuki T, Shimada SI, Shida K, Nanno M, Okumura K. Interleukin-12 is involved in the enhancement of human natural killer cell activity by Lactobacillus casei Shirota. Clinical and Experimental Immunology 146: 109-115 (2006)

Tiwari SK, Dicks LMT, Popov IV, Karaseva A, Ermakov AM, Suvorov A, Tagg JR, Weeks R, Chikindas ML. Probiotics at war against viruses: What is missing from the picture? Frontiers in Microbiology 11: 1877 (2020)

Todorov SD, Wachsman MB, Knoetze H, Meincken M, Dicks LMT. An antibacterial and antiviral peptide produced by Enterococcus mundtii ST4V isolated from soya beans. International Journal of Antimicrobial Agents 25: 508-513 (2005)

Todorov SD, Wachsman M, Tomé E, Dousset X, Destro MT, Dicks LM, Franco BD, Vaz-Velho M, Drider D. Characterisation of an antiviral pediocin-like bacteriocin produced by Enterococcus faecium. Food Microbiol. 27: 869-879 (2010)

Torres N, Sutyak N, Xu S, Li J, Huang Q, Sinko P. Safety, formulation, and in vitro antiviral activity of the antimicrobial peptide subtilosin against herpes simplex virus type 1 . Probiotics and Antimicrobial Proteins 5: 26-35 (2013)

Tuyama AC, Cheshenko N, Carlucci MJ, Li JH, Goldberg CL, Waller DP, Anderson RA, Profy AT, Klotman ME, Keller EK, et al. ACIDFORM inactivates herpes simplex virus and prevents genital herpes in a mouse model: optimal candidate for microbicide combinations. The Journal of Infectious Diseases 194: 795-803 (2006)

U.S. Food and Drug Administration. Emergency use authorization information. Available online: https://www.fda.gov/emergencypreparedness-and-response/mcm-legal-regulatory-and-policyfra mework/emergency-use-authorization. Accessed June 27, 2020.

Vajro P, Paolla G, Fazano A. Microbiota and gut-liver axis: A minireview on their influences on obesity and obesity related liver disease. Journal of Pediatric Gastroenterology and Nutrition 56: 461-468 (2013) 
Villena J, Oliveira ML, Ferreira P, Salva S, Alvarez S. Lactic acid bacteria in the prevention of pneumococcal respiratory infection: future opportunities and challenges. International Immunopharmacology 11: 1633-1645 (2011)

Vincent MJ, Bergeron E, Benjannet S, Erickson BR, Rollin PE, Ksiazek TG, Seidah NG, Nichol ST. Chloroquine is a potent inhibitor of SARS coronavirus infection and spread. Virology Journal 2: 69 (2005)

Wachsman MB, Farı̀as ME, Takeda E, Sesma F, de Ruiz Holgado AP, de Torres RA, Coto CE. Antiviral activity of enterocin CRL35 against herpesviruses. International Journal of Antimicrobial Agents 12: 293-299 (1999a)

Wachsman MB, Farias ME, Takeda E, Sesma F, De Ruiz Holgado AP, de Torres RA, Coto CE. Antiviral activity of enterocin CRL against herpes virus. International Journal of Antimicrobial Agents 12: 293-299 (1999b)

Wachsman MB, Castilla V, De Ruiz Holgado AP, de Torres RA, Sesma F, Coto CE. Enterocin CRL35 inhibits late stages of HSV-1 and HSV-2 replication in vitro. Antiviral Research 58: 17-24 (2003)

Wang Z, Chai W, Burwinkel M, Twardziok S, Wrede P, Palissa C, Esch B, Schmid MFG. Inhibitory influence of Enterococcus faecium on the propagation of swine influenza a virus in vitro. PLoS One 8: e53043 (2013)

Wang M, Cao R, Zhang L, Yang X, Liu J, Xu M, Shi Z, Hu Z, Zhong W, Xiao G. Remdesivir and chloroquine effectively inhibit the recently emerged novel coronavirus (2019-nCoV) in vitro. Cell Research 30: 269-271 (2020)

WHO. Cornonavirus disease (COVID-19) pandemic. Available at: https://covid19.who.int/. Accessed March, 15, 2021.

Xu Z, Shi L, Wang Y, Zhang J, Huang L, Zhang C, Liu S, Zhao P, Liu $\mathrm{H}$, Zhu L, et al. Pathological findings of COVID-19 associated with acute respiratory distress syndrome. Lancet Respiratory Medicine 8: 420-422 (2020)

Yang N, Shen HM. Targeting the endocytic pathway and autophagy process as a novel therapeutic strategy in COVID-19. International Journal of Biological Sciences 16: 1724-1731 (2020)

Yang SJ, Lee JE, Lim SM, Kim YJ, Lee NK, Paik HD. Antioxidant and immune-enhancing effects of probiotic Lactobacillus plantarum 200655 isolated from kimchi. Food Science and Biotechnology 28: 491-499 (2019)

Yasui H, Kiyoshima J, Hori T. Reduction of influenza virus titer and protection against influenza virus infection in infant mice fed Lactobacillus casei Shirota. Clinical and Diagnostic Laboratory Immunology 11: 675-679 (2004)

Yu HS, Lee NK, Choi AJ, Choe JS, Bae CH, Paik HD. Antagonistic and antioxidant effect of probiotic Weissella cibaria JW15. Food Science and Biotechnology 28: 851-855 (2019a)

Yu HS, Lee NK, Choi AJ, Choe JS, Bae CH, Jang HJ, Paik HD. Antiinflammatory potential of probiotic strain Weissella cibaria JW15 isolated from kimchi through regulation of NF- $\kappa \mathrm{B}$ and MAPKs pathways in LPS-induced RAW 264.7 cells. Journal of Microbiology and Biotechnology 29: 1022-1032 (2019b)

Zhang L, Lin D, Sun X, Curth U, Drosten C, Sauerhering L, Becker S, Rox K, Hilgenfeld R. Crystal structure of SARS-CoV-2 main protease provides a basis for design of improved -ketoamide inhibitors. Science 368: 409-412 (2020)

Publisher's Note Springer Nature remains neutral with regard to jurisdictional claims in published maps and institutional affiliations. 